\title{
THE STUDENTS' RESPONSES TOWARD THE IMPLEMENTATION OF PICTIONARY GAME IN TEACHING VOCABULARY TO THE SEVENTH GRADE STUDENTS IN ONE OF JUNIOR HIGH SCHOOL IN CIMAHI
}

\author{
Indri Kartini $^{1}$, Evie Kareviati ${ }^{2}$ \\ 1,2 IKIP Siliwangi \\ ${ }^{1}$ indrikartini@student.ikipsiliwangi.ac.id, ${ }^{2}$ ekareviati@gmail.com
}

\begin{abstract}
This study is aimed to find out the students' responses toward the implementation of Pictionary game technique in teaching English vocabulary to the seventh-grade students. The study was conducted at SMP Dharma Kartini. The students of VII C class that consists of 38 students were selected as the participants of the research. The research used descriptive qualitative method. The data of the research was obtained from observation during the implementation of Pictionary game in the class and from the students' interview that has conducted to 5 students. The result showed that Pictionary game technique is useful to draw the students' motivation in learning English vocabulary. From the data of observation showed that the Pictionary game made the students more active to get involved in teaching and learning process actively. The students also showed good responses from the data of interview, they stated that learning by using Pictionary game was fun but also challenging which make them motivate in learning English. Thus, it can be concluded that Pictionary game is an attractive technique that can be used to motivate students in learning vocabulary and make the students to learn English vocabulary in a more fun and creative way.
\end{abstract}

Keywords: Pictionary Game, Vocabulary

\section{INTRODUCTION}

Vocabulary is an important component for students in learning a foreign language. Through having a lot amount of words, it enables students to master English four skills such as speaking, writing, reading, listening easily and effectively. As Murcia (2001: 285) in Nurdiansyah, Asyid, \& Parmawati (2019) states that vocabulary learning is central to language acquisition, either the language is first, second or foreign. In addition, McCharty (1990) as cited in Darmawan \& Fatmawati (2019) states that vocabulary is the experience of most language teachers which plays an essential part in any language course. Thus, vocabulary can be considered as a crucial aspect that students necessary to learn in learning a language.

Moreover, no matter how well students learn the other English four skills but without words to express a wide range of meanings, communication in the second language just cannot happen and nothing can be conveyed. Mastering vocabulary enables students to achieve the success of learning English.

However, even though English is important and has been a compulsory subject in Indonesia, many students who have been graduated from school still have the minimum ability in mastering vocabulary. The problems which caused students to find that learning English is 
difficult are the student is not interested in learning English because of the way the teachers who deliver the material monotonously and mostly teacher-centered, while the other reason is due to less motivation in learning English. This statement in line with Cahya, Kusnadi, \& Anggraeni (2018) that state one of the causes of Indonesian students thinks that learning English is difficult is due to a lack of motivation. On the other hand, motivation also plays a great role in the learning process that cannot be neglected by teachers.

In solving those problems, a teacher needs to find a suitable and attractive technique to increase students' interest and draw their motivation in learning English. One of the techniques which can be implemented is using a game. Furthermore, seventh-grade students are considered young and they tend to prefer learning in such an enjoyable and fun situation. Harmer (2001) as cited in Lube \& Nuraeni (2020) states that games can make students more active and enthusiastic in learning vocabulary. Furthermore, Gruss (2016) as cited in (Ayu, 2018) explains through using games as a tool in teaching English vocabulary, the result showed various views on how entertaining the games could be in teaching young learners. Besides, game is fun to be taught to students. By using a game as a technique in teaching vocabulary, it enables teacher in observe students' personalities, teach them how to work as a team to build their relationship with the others, and also practice students various skills in more fun ways. Therefore, in this study, the writer will implement Pictionary game as a technique in teaching vocabulary to seventh-grade students.

According to Thornbury (2002) as cited in Darmawan \& Fatmawati (2019) Pictionary game is a game that involves the students in guessing words or phrases from drawings. Pictionary game is a game that requires students to work in teams and each member of the team takes a turn to be the artist. Pictionary game is an interesting game that can help students to increase their motivation in learning English. Through playing Pictionary game, students who inactive before might be interested and be more active than before. This is due to Pictionary game requires the students to work in a group to help each other in guessing the word. Furthermore, Pictionary game enables students to understand the words and their functions in learning English and helps them to memorize the vocabulary easier because the students produce the words by drawing and guessing by themselves. Hence, the writer's desire to implement Pictionary game as a technique in teaching vocabulary to seventh-grade students to find out the students' responses toward its use and expected can help to motivate the students in learning English vocabulary.

\section{LITERATURE REVIEW}

\section{Vocabulary}

According to Linse (2002:121), as cited in Santoso \& Andriyadi (2019), vocabulary is the collection of words that an individual knows. Vocabulary plays a great role in learning a language. Furthermore, Kmorowska (2005) cited in Nurdiansyah, Asyid, \& Parmawati (2019) state that recently, the basic purpose of language learning is communication, and vocabulary plays an important role in the conversation. Thornbury (2002) as cited in Hamer and Rohimajaya (2018) classified vocabulary in two terms, they are active and passive vocabulary. Active vocabulary refers to the use of items appropriately in speaking and writing and it also called productive vocabulary. Meanwhile, the passive vocabulary refers to a language item that can be recognized and understood in the context of reading and listening, this vocabulary also called receptive vocabulary. Furthermore, Thornbury explained that there are several kinds of content of words which consist of noun, verb, adjective, adverb, pronoun, conjunction, interjection, and preposition. 
However, in this study, the writer only focuses on noun, mainly at list of words such as profession (person) and things that suitable for the material being taught in the teaching and learning process. Therefore, due to Pictionary game requires the students to draw, the writer only used concrete nouns to enable the students to draw the vocabulary.

\section{Pictionary game}

Rauschenberg (2009) as quoted in Darmawan \& Fatmawati (2019) explains that Pictionary game is a word game that used to improve students' vocabulary by guessing the words from drawing. Pictionary game is a simple game that does not need a lot of preparation. The materials that are used in playing Pictionary game, such as a list of cards of vocabulary items, whiteboard, chalkboard, or smartboard and markers or chalk. In this study, the list of words used are animals, things around us, and about the profession. However, in guessing about profession the students who in charge as the painter do not have to draw fully because it will be too hard and challenging for the students, they only need to draw from the keywords related to vocabularies about the profession given by the teacher.

Hamer \& Lely (2019) elaborate the steps to apply Pictionary game in the classroom. There are as follows:

a. Learners are divided into a group. The number of the group can be depending on the number of learners in the classroom and also can be divided based on the seat.

b. The teacher explains the rules of Pictionary game.

c. Each group is given a word to draw.

d. Each group determines the others to draw and also to illustrate every word given by the teacher. The other can be the learners who sit down in front of the classroom and or on the backside.

e. The teacher who puts a collection of that word will draw in the front desk, along with a blank sheet of paper for drawing several words to each of the learners.

f. After all learners ready, the teacher gives the warning to start and each of the learners starts to play it.

g. After a warning, one member of each group begins to take one of the cards and begin to draw, and then tell the members of the group to guess (students who are drawing only answer, yes ${ }^{\circ}$ if true and ,no if false).

h. Each learner as members of the group takes turns to go forward to take one of the card words and draws to guess by members of the group.

i. The winner is the most and the fastest group when guessing the words correctly.

However, in implementing the Pictionary game to students, the writer modified several steps and the rules-based on lesson plans of each meeting which adjusting with the materials and the situation in the classroom.

\section{METHOD}

This study used descriptive qualitative method. This method was chosen because the data of the study would be presented in a form of description. Alwasilah (2002) as cited in Ibrohim, Septiani, and Sadikin (2018) state that descriptive research describes characteristics or identifies a group, accident, and phenomenon by which technique commonly used. 
This study was conducted in SMP Dharma Kartini with the participant of the study was the students of VII C which consists of 38 students. The data of the study were collected from interview and observation. The observation used to obtain information based on the implementation of Pictionary game technique during the learning process take place in the class. Marshall \& Rossman, 1998, p.79) as cited in Nurmalasari \& Apsari (2019) state that observation is the systematic description of the events, behaviors, and artifacts of a social setting. In this study, the observation was used to obtain information on students' participation and responses regarding the implementation of the Pictionary game technique during the learning process that takes place in the classroom.

Thus, the English teacher was being involved in the process. The English teacher helped the researcher to observe the activity from both the students and the researcher during the learning process occur in the classroom. Kvale (1996: 174) as cited in Nurmalasari \& Apsari (2019) states that interview is "a conversation, whose purpose is to gather descriptions of the life-world of the interview with respect to interpretation of the meanings of the "described phenomena". In this study interview was used to get deeper information based on students' perceptions and responses toward learning vocabulary by using Pictionary game.

\section{RESULTS AND DISCUSSION}

\section{Results}

The interview was given after the implementation of Pictionary game was done in three meetings. The interview was obtained to find out the students' responses and perceptions toward learning vocabulary by using Pictionary game in the class. The interview has been conducted with 5 students. The researcher selected those students due to their different levels of the participant in the classroom. Furthermore, the interview consists of 10 questions, they were elaborated as follows:

\begin{tabular}{lll}
\hline No & Question & Students' Responses \\
\hline 1. & $\begin{array}{l}\text { Do you like to learn } \\
\text { English? }\end{array}$ & $\begin{array}{l}\text { Three of them stated that they like to learn English because } \\
\text { it was fun. Meanwhile, two of them did not like it. The } \\
\text { reason they did not like English because they thought that }\end{array}$ \\
& $\begin{array}{l}\text { English was difficult and they did not understand its } \\
\text { meaning. One student said that the vocabulary was hard to } \\
\text { remember. }\end{array}$
\end{tabular}

2. Do you like it when the teacher teaches about vocabulary?

All of them stated that they like to learn vocabulary because it helps their English skill. When they knew the English vocabulary well, it will enable them to understand the English language easier.
3. What do you think The students said that studying in groups was quite about studying in effective. Besides, the learning process became more groups? Is it effective exciting, the students also can help each other in the or not? material context. They can discuss the material together in solving the assignments given by the teacher and helping each other when they had difficulties in understanding the task


4. What do you think Most respondents said that they like to learn English using about learning using pictionary game because it was a different way of teaching Pictionary game? than usual. They stated that learning English vocabulary by using Pictionary game was fun and made them enjoy the learning process.

5. Are there any Most of them thought that they did not have any big difficulties during problems or difficulties while playing pictionary game. learning English using They could play the game quite well. Also, one student Pictionary game? stated sometimes the difficulty was only when they got the difficult words to illustrate, they had to imagine of a drawing that the clues would be easily guessed by their friends.

6. Do you think learning using Pictionary game makes you remember the material and the vocabulary that is taught easily?

All of the students stated that pictionary game was useful to retain the new vocabulary they learn. Pictionary game helps them remember the new vocabulary they learn because the students produce the words by themselves through drawing and guessing the vocabulary.

Do you think learning using Pictionary game helps your vocabulary mastery?
The students stated that Pictionary game did help their vocabulary mastery in learning English.
8. $\quad$ Does playing Pictionary game make you motivated or interested in learning English?
All of the students said that pictionary game motivated them to learn English. The learning process became more fun but challenging which made the students interesting to get involved actively. One student even stated that she used to did not like English that much but after playing pictionary, she started to like it.

The students said that pictionary game did practice their creativity skill because they can express the vocabulary into drawings. Especially when the students became the painter, they need to visualize a drawing that would be easily guessed by their friends. Thus, the students tried to give their best to draw as creatively and accurately as possible.

10. Do you think learning The students all agree that pictionary game was useful to vocabulary using Pictionary game is useful to motivate students in learning English?

\section{Discussion}

Referring to the data gained from the interview, most respondents showed good responses toward learning vocabulary by using Pictionary game. The students stated that the learning process became more exciting and made them enjoy during the lesson. By playing Pictionary 
game attracts the students' motivation to get engaged actively because this game requires the students to work in groups and they need to cooperate with each other during playing Pictionary game.

The statement from the students' interview also supported by the data from the observation sheet which the students' participation was being observed during the Pictionary game was implemented in the classroom. The English teacher being involved to help the researcher in observing the students by assessing the aspects presented in an observation sheet.

Thus, the students' participation during Pictionary game was implemented in the classroom is described as follows:

In the first meeting, the researcher introduced Pictionary game to the students by giving a demonstration of how to play Pictionary game in the classroom. The researcher gave an example by drawing a few illustrations of common words that the students would have known the vocabulary easily. Most of the students were curious about Pictionary game and were eager to try it. Considering the number of students who consist of 38 students in the classroom, cooperative learning was implemented during the teaching process. Therefore, the researcher divided the students into six groups and gave them instruction and the rules while playing Pictionary game. The students were listening to the instruction and followed the rules well.

However, because it was the first attempt in playing Pictionary game, the researcher gave vocabularies related to things around them either it was about animals, tools, etc that the students familiar with. The researcher gave a chance to the students who wanted to tried to be the painters while the rest of the students need to answer the vocabularies which had been drawn by the painters. The team who answered the most would be the winner. Half of the students participated actively in being involved during the lesson and volunteer themselves as the painters because they were excited about the uncommon technique used in teaching than usual. During playing the game, the painters did not find any major difficulties yet. Meanwhile for the other students that need to guess had difficulty in guessing the vocabularies because they did not know the words in English. Moreover, the researcher decided to allow the students looked upon their dictionary to help them answer the words in English. In that case, it can be seen that the students have low vocabulary skill.

Even though the students showed good responses toward learning vocabulary by using Pictionary game in the first meeting, some students were still passive and timid during the lesson. The students were still hesitant and shy to tried to be the painter because they were afraid that their drawings would be bad and few of them did not contribute guessing the vocabularies while the other students enthusiastically guessed the words.

Thus, at the end of the learning process, the researcher told them to engage actively to help their groups to answer the vocabularies. The researcher also gave courage and some advice to the students that in playing Pictionary game, they did not have to be good at drawings but this game was requiring a good strategic or thinking out of the box at drawing the vocabulary in order the words could be guessed easily by the others. It means, that playing Pictionary game is not about an artistic talent but it is about students' creativity skill.

In the second meeting, the material being taught was about professions. The students learned about several professions and their jobs. However, in this meeting, Pictionary game was implemented at the end of the learning process in which the material had been delivered first. 
The students were given the assignment to match the profession and its jobs correctly with their groups. Hence, the purpose of Pictionary game was given at post-activity to review the material that had been taught and to recall the important vocabularies during the learning process about profession had been learned. In playing Pictionary game at the second meeting, the students were divided based on their previous groups to maximize the remaining time of the lesson effectively. Each group needs to appointing two students as the painters while the rest of the students need to help their own groups guessed the vocabularies drawn by each painter correctly.

Because the vocabularies were about professions, that means it was related to people and it would be too difficult for the students considering they only played this game once. Moreover, the researcher asked the students to only draw the keywords of those particular professions. However, before playing the Pictionary game, the researcher gave a stimulation by asking the students some questions related to the topic of the profession that had been taught by saying:

"What words crossed at your minds when you heard about a fisherman?"

The answers were various such as "Ikan (Fish)", "Air (water), "Laut (Ocean)", "alat memancing (fishing rod)" etc. and then, they were given a drawing related to another profession. The researcher drew an eye and they were automatically answering an "optician".

After that, the researcher gave an illustration to the students on how to play the Pictionary game related to the profession. At this second meeting, the students participated and engaged more actively in playing Pictionary game compared to the first meeting. Most of them excited to guess the clues given by the painters' drawing passionately and they did remember all of them because the students had been learned the material before. The students did a great job of guessing the keywords that had been drawn.

The painters also drew unexpected drawings, they have given such a clear illustration for their friends to guess. There was a student who drew a needle and a yarn to give a clue about "Tailor" profession, there was a student who drew an egg to give a clue of "Chef" profession and there was a student who drew a rocket and a star to give a clue about "astronomer" profession. During playing the Pictionary game, the students were unexpectedly really creative in delivering the clues, and the rest of the students could be guessing and knew the vocabularies well.

However, because the students were too excited and competitive during playing the Pictionary game it caused the class to become a bit noisy and uncontrolled. But even though it was difficult to be handled, the learning process still could be managed well until the end of the lesson. Moreover, it showed that the students' enthusiasm to learn English by using Pictionary game was high.

In the last meeting, the vocabulary was related to things and their function. The researcher modified the Pictionary game became a race, where the students were divided into two teams and competing between each other in guessing the vocabularies. The team who guesses the vocabularies the most would be the winner. However, the rules of the Pictionary game were different from the first and previous meetings that the students who were in charge as the painters were limited. At this meeting, all the students had a chance to draw because they took a turn as the painters. The students only had one chance as the painter and need to pass the job 
to the others who had not gotten the chance yet. The duration of the game was only twenty minutes before the material was being taught. At this meeting, Pictionary game was given at the pre-activity to stimulate the students in enriching their vocabulary mastery towards material that would be given.

During playing the race, the students were becoming more enthusiastic to play Pictionary game because they desire to win the game. All of the students participated enthusiastically to guess the words drew by their teammates as quickly as possible because they wanted to get the point. Unlike the last two meetings, the students who were inactive before started to bravely try to be the painters. However, due to the number of students and lack of time, there were still a few students who had not gotten the chance as the painters yet. Therefore, the duration of the time for playing Pictionary game was slightly extended. After the game was ended, it showed that Pictionary game did help the students to increase their motivation in learning English.

From the observation that has taken by the researcher, Pictionary game is useful to draw the students' motivation in learning English vocabulary. The students showed their high enthusiasm to learn English by using Pictionary game. This statement is supported by theory from Harmer (2007) as cited in Ayu (2018) states that Pictionary is one of a game that is designed to engage students and motivate them in learning vocabulary. Most of the students showed interest and excitement in learning English by using Pictionary game technique that had been done in 3 meetings. The students have engaged actively and put an effort to participate in the learning process than the first meeting.

\section{CONCLUSION}

Based on the result and discussion above, it can be concluded that Pictionary game is useful to draw the students' motivation in learning English. That can be seen from the students' interview and their participation that being observed during the teaching process occurred in the class. From the data gained by the interview, the students gave positive responses from all the questions related to learning English by using Pictionary game. The students feel motivated and they thought that the learning process became exciting and challenging but also fun. The vocabulary tends to easier to memorize because the students guessing and drawing the words by themselves.

Meanwhile, the data gained from the observation showed that the students engaged actively in all aspects written in the observation sheet. The students became more excited and they showed high enthusiasm in each meeting to learn English vocabulary by playing Pictionary game. Pictionary game made the students to being involved actively during the learning process because this game is mostly student-centered.

In addition, besides Pictionary game is fun this game also practicing the students' creativity skills. The implementation of Pictionary game was good to drills the students' creativity because the students who became the painter needs to be creative in imagining and drawing the words accurately in order can be guessed easily by their friends. Thus, Pictionary game is an interesting technique that can be used to motivate students' in learning English vocabulary and showing them an attractive way of teaching than usual. Pictionary game makes the students to learn vocabulary in a more fun and creative way. 


\section{ACKNOWLEDGMENTS}

First of all, the writer would like to thank Allah SWT, all praises be to Allah SWT who has given strength and opportunity to complete this study. This article can be finished with the help of several people during the process. Thus, the writer would like to thank my lecturer for her guidance in helping me to finish this article. Thanks to my family who has supported me. Thanks to my friends who have given me suggestions and courage during the research process until this article has been completed fully.

\section{REFERENCES}

Ayu, R. R. (2018). The Effect of Using Pictionary Games on Students English Vocabulary. Teacher Training and Education Faculty, 9.

Cahya, T., Kusnadi, A. N., \& Anggraeni, A. (2018). the Influence of Tangible Rewards To Student'S Motivation in 4Th Grade Sdn Sinargalih 1 Ciranjang Students. PROJECT (Professional Journal of English Education), $1(4), \quad 350$. https://doi.org/10.22460/project.v1i4.p350-356

Darmawan, S. L., \& Fatmawati, G. N. (2019). Intensive Journal. 2(1), 1-8.

Hamer, W., \& Lely, L. N. (2019). Using Pictionary Game to Increase Learners' Vocabulary Mastery in English Language Instruction. Journal of English Education Studies, 2(1), 4351. https://doi.org/10.30653/005.201921.30

Hamer, W. Rohimijaya, A. (2018). Using Flash Card as Instructional Media to Enrich the Students' Vocabulary Mastery in Learning English. Sultan Ageng Tirtayasa University. Journal of English Education Studies, 167-177, Vol. 2 No. 3

Ibrohim, T.A., Septiani, A. Sadikin, I, S. (2018). Students' Perception Toward Teaching English Vocabulary Through Total Pyshical Respon (TPR) Method. PROJECT (professional Journal of English Education), Vol. 1 No.2

Lube, C. I., \& Nuraeni, S. (2020). Improving English Vocabulary Mastery Through Word Game. PROJECT (Professional Journal of English Education), 3(1), 109. https://doi.org/10.22460/project.v3i1.p109-113

Nurdiansyah, D. M. R., Asyid, S. A., \& Parmawati, A. (2019). Using Color Coding To Improve Students'english Vocabulary Ability. Project (Professional Journal Of English Education), 2(3), 358-363. https://doi.org/10.22460/project.v2i3.p358-363

Nurmalasari, M., \& Apsari, Y. (2019). Improving Students'participation In Speaking English Using Snowball Throwing Technique. Project (Professional Journal of English Education), 2(2), 115-121.

Santoso, I., \& Andriyadi, A. (2019). the Use of My Dictionary Application To Improve Students' Vocabulary Mastery. ELTIN JOURNAL, Journal of English Language Teaching in Indonesia, 7(1), 35. https://doi.org/10.22460/eltin.v7i1.p35-42 